\title{
COMPARATIVE ANALYSIS OF FUNCTIONAL FOOD PRODUCERS' PROFITABILITY IN SERBIA - A LEADER-FOLLOWER RELATION ${ }^{1}$
}

\author{
Dragana Draganac ${ }^{2}$
}

\begin{abstract}
Summary
The functional food market in Serbia is relatively young and insufficiently explored both from the aspects of producers and consumers, the qualitative aspect and especially from the quantitative aspect. The aim of this paper is to illustrate the results of the comprehensive quantititative financial analysis of profitability which focuses on the example of two companies. The main criterion applied in the selection of companies for the analysis represents the fact that one company is recognizable as a producer of foods with nutritive and health claims and is a leader within that market segment, whereas the other analyzed company mostly produces traditional products and has entered the aforementioned market segment at a later stage. The key idea is to do a comparative analysis of the profitability of these two companies for a four-year period. The profitability ratio analysis and the Du Pont analysis system are used in the paper as well as the analysis of solvency and financial leverage effect. The vertical analysis of income statement is also done in order to reveal the relation between some cost categories and operating revenues. The research results lead to a conclusion that the company that mostly produces functional foods has higher profit margins and rates of return and is therefore in a more favourable position since it can benefit from positive effects of financial leverage to a higher extent. The profitability of the second relevant company is mostly based on the better asset turnover.
\end{abstract}

Key words: profitability, financial leverage, functional food producers

JEL: M49, G30, Q19

1 The paper is the result of the quantitative research conducted as part of the projects financed by the Ministry of Education, Science and Technological Development: Project III 41030 "Biological effects, nutritional intake and status of folate and polyunsaturated fatty acids: The improvement of nutrition in Serbia" (working package 5: Nutrition and consumer) and Project III 46001 "The development and application of new and traditional technologies in the production of competitive alimentary value added products for the European and world market - make the wealth from the wealth of Serbia".

2 Dragana Draganac, Teaching Assistant, Faculty of Economics, University of Belgrade, Kamenička Street no. 6, 11000 Belgrade, Republic of Serbia, Phone: +381 1130211 77, E-mail: dragana_c@ekof.bg.ac.rs

EP 2016 (63) 2 (547-566) 


\section{Introduction}

Functional foods have for a long time been a point of interest of many natural sciences (medicine, biology, food technology, etc.), but they have insufficiently been researched from the point of view of economics. However, with an increased promotion of the benefits of a healthy lifestyle, the need for a better standard of living as well as with the heightened awareness about the importance of including these consumer products in our everyday diet, the focus of economic research has also shifted to include the domain of functional foods. The functional food market has become especially interesting for economic analysis over the course of the past few years primarily because of its important commercial potential. The growth of the functional food market in Serbia has particularly been strong over the last four years, especially because of the rise in the number of functional food consumers, and this tendency is also expected in the future (Stojanović et al., 2014).

The term "functional food" stands for the food that contains some useful nutritive ingredients, such as probiotics, vitamins, minerals, omega-3 fatty acids, etc. the regular consumption of which has positive effects on our health both in preventive and curative terms (available at: http://www.somboled.rs/en/magazine/healthy-diet/functional-food). The most representative foods are mainly found in the category of dairy and fruit products.

Functional foods are consumer products which, in addition to providing an organism with sufficient nutrients for the normal functioning and satisfying our basic physiological needs, also have an important supplementary role: they reduce the risk of disease, or prevent the further progression of a disease through their beneficial physiological and psychological effects (Diplock et al., 1999).

A nutritive claim is a statement which offers confirmation that the product contains some nutrients or that it contains high/low levels of some ingredient (high level of vitamins, $0 \%$ of fat, etc.). Health claims usually point out that nutrients have positive effects on some body functions or that they reduce the risk of the occurrence of a certain disease (Mitic et al., 2014).

Foods with nutritive and health $(\mathrm{N} \& \mathrm{H})$ claims are not only targeted at vulnerable consumer groups, i.e. the ones that experience chronic health problems such as noncommunicable diseases (diabetes, cardiovascular diseases, etc.), but also at pregnant women, sportsmen, children and everyone who is aware of the relationship between the quality of nutrition and health. In the beginning, the targeted consumer groups were young, educated women with high incomes who live in urban areas, but the scope of the target group is now gradually expanding to include members of the elderly population with a medium range of income (Stojanović et al., 2013, b).

More N\&H claims are found on products which are traded on unregulated functional food markets than on the regulated ones. In Serbia, for example, numerous N\&H claims can be viewed as being unattestable as they are very vague and general, or may even be confusing and induce consumers to arrive at wrong conclusions about certain product characteristics (Dragutinović Mitrović et al., 2014). 
It is of utmost importance to improve regulations referring to product labeling and the use of nutritive claims in Serbia. Regulations pertaining to health claims are still nonexistent in Serbia. As a consequence of regulatory oversight and/or the general absence of regulations, some producers in Serbia are given the opportunity to manipulate the consumers by the inadequate use of $\mathrm{N} \& \mathrm{H}$ claims, which ultimately creates mistrust between the consumers and is certainly one of the main reasons of the insufficient consumption of functional food products.

When it comes to the evaluation of motives for the N\&H claimed food production and selling in the Western Balkan countries, the producers and retailers most often cite the improvement of a company's image and the need to respond to consumer demands (Stojanović et al., 2013, a). One shoud be careful in considering profit as a motive, having in mind that the list and the ranking of the relevant motives is usually compiled and obtained by means of in-depth interviews. We should also bear in mind that the answer which includes profit as the main motivation is very likely to be avoided due to its socially inappropratite connotations.

This paper focuses on the analysis of the causes of difference in profitability between the two companies from the same industry. The main distinction between the two relevant companies is the structure of the product assortment (functional vs. traditional food) and the moment of their entering the N\&H claimed product market. The rationale behind the choice of these two particular companies lies in the fact that the very emergence of the functional food markets in Europe and Serbia is directly related to dairy products.

\section{General remarks about analyzed companies}

„Imlek" is a regional company that is constantly investing in modern technology, staff, the quality management system, the food safety system and environmental protection which ultimately yields high quality products that have been presented with numerous awards and certificates (available at: www.imlek.rs/en).

The company produces more than 80 different dairy products. Besides the commonly recognizable brands, such as "Moja Kravica” (My Little Cow) yogurt, it especially invests in the segment of functional products which provides the consumers with dairy products with added ingredients that positively affect different aspects of the healthy functioning of the human organism. Moreover, „Imlek“ has a product range called „Bello“, which includes the first $100 \%$ organic products in Serbia. The company produces products which are rich in vitamins, minerals, probiotics and fiber that improve digestion, boost metabolism, strengthen the immune system, or reduce body mass and the percentage of fat in the body by converting fat into energy in a natural way.

"Somboled" is currently one of the most successful dairy industry companies in Serbia and that stable position is furher ensured with its continual investment in primary milk production and new innovative dairy products. Within its product range, the company has brands such as „Dukat" and „President" which are one of the best known brands of dairy products in Serbia and in the region. By looking at the product assortment of the company, it is clear that traditional products which satisfy the gastronomic preferences of gourmets 
are the most dominant ones (available at: www.somboled.rs).

In the domain of functional foods, „Somboled“" produces Dukat UHT milk which is enriched with 7 essential vitamins and folic acid. Some yogurts are rich in probiotics which regulate digestion and balance the intestinal microflora in a natural way, simultaneously boosting the immune system. ,Dukat" chocolate milk is enriched with vitamins and folic acid which makes this brand of chocolate milk especially convenient for the the needs of growing children. The company also produces products with a very low percentage of milk fat, as well as those that are rich in calcium.

\section{Hypotheses, methodology and data sources}

This paper illustrates the results of the financial analysis and the comparison of profitability of the abovementioned companies. The key point of research revolves around identifying the causes of differences in the profitability as well as around identifying value creation methods.

In the course of the analysis, I have applied the profitability ratio analysis as well as the Du Pont system analysis. In identifying the specific causes of difference in profitability, it was necessary to analyze solvency, financial leverage, some turnover ratios and cost structure. This paper relies on the data obtained from publicly available financial statements of these two companies.

It is to be expected that "Imlek" should have higher profit margins and higher rates of returns in comparison with "Somboled", but it should also be apparent that this company has higher specific kinds of costs, such as marketing costs, sponsorship costs, research and development costs, costs of raw milk, costs of the quality analysis of final products, consultancy costs, etc. This assumption seems even more plausible if we take into account the fact that this company has a wider range of N\&H products and that it has produced functional foods for a longer period of time in comparison with the other company.

In accordance with the defined scope of this paper, the main research objective is to reveal whether „Imlek“ has higher profitability and different ways of increasing profitability in comparison with ,Somboled“. The following hypotheses are tested in this paper:

H1: The company that is recognizable as a functional food producer has higher profit margins.

$\mathrm{H} 2$ : The company that mostly has traditional products in the product assortment uses the strategy of higher asset turnover.

H3: The cost structure of the company that mostly produces N\&H products is different from the cost structure of the company that has a smaller number of N\&H products in its product assortment.

H4: The company that is recognizable as a functional food producer can afford and benefit from higher levels of financial leverage because it has higher rates of return. 


\section{Research results}

As mentioned above, for the purpose of this research I have applied the ratio analysis of revenue profitability, the ratio analysis of asset and equity profitability, as well as the Du Pont system analysis. ${ }^{3}$ I have also analyzed the cost structure, i.e. the relation between some specific cost categories and operating revenues.

\section{Ratio analysis of profitability}

For the purpose of the ratio analysis of revenue profitability, I have calculated, interpreted and conducted a comparative analysis of the following ratios: gross margin, operating profit margin, net profit margin and EBIT margin. The ratio analysis of asset and equity profitability has been applied across the following ratios: return on asset ROA and return on equity - ROE.

The profitability ratios for the companies „Imlek“ and „Somboled“ for the four-year period (2010-2013) are shown in the table below.

Table 1. Profitability ratios: "Imlek" vs. "Somboled", 2010-2013

\begin{tabular}{|l|c|c|c|c|c|c|c|c|}
\hline \multirow{2}{*}{ Year } & \multicolumn{2}{c|}{$\mathbf{2 0 1 0}$} & \multicolumn{2}{c|}{$\mathbf{2 0 1 1}$} & \multicolumn{2}{c|}{$\mathbf{2 0 1 2}$} & \multicolumn{2}{c|}{$\mathbf{2 0 1 3}$} \\
\cline { 2 - 9 } & Imlek & Somboled & Imlek & Somboled & Imlek & Somboled & Imlek & Somboled \\
\hline 1. Gross margin & $51.12 \%$ & $37.71 \%$ & $50.42 \%$ & $34.17 \%$ & $52.94 \%$ & $35.80 \%$ & $52.85 \%$ & $35.20 \%$ \\
\hline 2. Op erating profit margin & $14.89 \%$ & $3.41 \%$ & $14.45 \%$ & $5.12 \%$ & $15.40 \%$ & $9.64 \%$ & $15.59 \%$ & $8.14 \%$ \\
\hline 3. Net profit margin & $6.33 \%$ & $0.56 \%$ & $10.15 \%$ & $3.55 \%$ & $12.53 \%$ & $5.07 \%$ & $10.62 \%$ & $5.09 \%$ \\
\hline 4. EBIT margin & $7.31 \%$ & $1.19 \%$ & $11.12 \%$ & $3.88 \%$ & $13.94 \%$ & $5.29 \%$ & $13.15 \%$ & $5.14 \%$ \\
\hline 5. ROA & $7.84 \%$ & $1.61 \%$ & $12.48 \%$ & $6.37 \%$ & $14.79 \%$ & $9.47 \%$ & $11.12 \%$ & $8.65 \%$ \\
\hline 6. ROE & $12.08 \%$ & $1.08 \%$ & $19.68 \%$ & $8.25 \%$ & $25.94 \%$ & $12.87 \%$ & $21.76 \%$ & $11.57 \%$ \\
\hline
\end{tabular}

Source: Calculations made by the author on the basis of financial statements available at: http://fi.apr. gov.rs/prijemfi/cir/objavljivanje.asp ${ }^{4}$

It can be seen that there are variations in profitability indicators both between and within observed companies. Generally speaking, the sources of variation in profitability can be classified into four groups: country, industry, corporate group and firm-level determinants. Country level determinants include law system, financial and technological infrastructures, access to international markets, etc. The examples of industry-level variables are: economics of scale, entry and exit barriers, market share, etc. Corporate group effects include advantages or disadvantages of individual firm's membership of a larger corporation. Internal firm-level factors that may cause difference in profitability are: internal strenghts and weaknesses, organizational structure, management practices, competitive positioning,

3 Formulas used for calculation of all ratios used in the paper are given in the Appendix 1.

4 http://fi.apr.gov.rs/prijemfi/cir/Podacil .asp?Search=07042701\&code=29d1 ebedc140fd4d8 e3f0eada5bde 7cb8175d006

http://fi.apr.gov.rs/prijemfi/cir/Podaci1.asp?Search=08067953\&code=00ce7a74d7b161b83 dfc00b86abbf96327038c33)

EP 2016 (63) 2 (547-566) 
product assortment structure, technical expertise, etc. (Goddard et al., 2009). In present paper I analyze the difference in the product assortment and leader - follower relation as a factors that may cause the difference in profitability between two analyzed companies.

The "Imlek's" gross margin is quite stable in each of the observed years and shows signs of a slight increase in both 2012 and 2013. The same tendency can be noticed in the analysis of the operating profit ratio which reflects the company's core business profitability without taking financing and tax effects into consideration. However, it can also be noticed that the operating profit margin appears to be only slightly higher in 2013 than in 2012. The net profit margin increased 4 percentage points in 2011 from 2010. The ratio also increased in 2012, but its decrease of less than 2 percentage points in 2013 from 2012 is worrisome. Even though we can observe a slight growth in sales revenue in 2013 from 2012, the net profit is significantly decreased, which means that the sales revenue contain less net profit, which is of course a bad indicator. A deeper analysis can be conducted in order to reveal which cost categories have risen and in turn led to a decrease in the net profit margin. In 2013 the cost of the sold goods rose significantly, but the main cause of fall in net profit was a drop in financial income that resulted in higher net financial expenses. The EBIT margin has a trend which is similar to the net profit margin ratio.

The return on asset ratio increased in the period from 2010 to 2012 . In 2013 it decreased to $11.12 \%$ from $14.79 \%$ in 2012 . Although there was an increase in the total asset investment, it resulted in a lower corresponding concept of profit ${ }^{5}$, which is bad for the company. In the following sections of the paper I will show the two-component ROA in the Du Pont analysis system that will enable me to analyze the causes of the ROA decrease in greater detail - through revenue profitability and asset management efficiency analyzes. It is important to have in mind that the level of ROA partly depends on the industry's features while partly on strategy choice and implementation (Malinić, 2013). Although both analized companies belong to the same industry and it is expected that they have the similar degree of operating leverage, the fact that „Imlek“ is more oriented toward functional food production than ,Somboled“ may cause different level and structure of costs, difference in production technologies, and as a consequence, different operating leverage, asset turnover and profit margins. The change in ROA is also influenced by product life cycle: the height of operating income and invesments are different during different phases of product life cycle (Seling, Stickney, 1989).

The return on equity increased significantly in the period from 2010 to 2012, but there was a drastic fall in 2013 of as much as 4 percentage points. I have already noticed a decrease in net profit in 2013 and have identified the reasons. The increase in the average net equity is also notable because it means that investments were rising, but that they also generated less amount of net profit, which is an unfavorable situation for the analyzed company. More detailed insights into the causes of ROE changes will be given within the Du Pont analysis system when I present a two-component and a four-component ROE. I will also analyze

5 Net profit + Interest Expenses*(1-Tax Rate). See formulas in the Appendix 1. 
revenue profitability, the equity turnover ratio and, for the first time, the capital structure and the effect of financial leverage.

I now turn to the analysis of the profitability of "Somboled". Its gross margin reached the highest point in 2010. It decreased in 2011 but in the following two years it remained stable, at the level of about $35 \%$. However, this ratio is significantly lower than the same ratio calculated for "Imlek" within the given time period - in 2013 alone, the difference amounted to 17.65 percentage points. The operating profit margin showed signs of growth in the period from 2010 to 2012, but dropped in 2013. Sales revenue decreased, but the operating profit was decreasing at a higher rate, and, as a consequence, the sales revenue contained less operating profit. This is a bad indicator for "Somboled", especially if we have in mind that its operating profit margin is considerably lower than "Imlek's". The net profit margin of "Somboled" stood at a very low level of only $0.56 \%$ in 2010 when the company earned the lowest amount of net profit. The net profit margin increased in the following years, but reached a level of only 5.09\% in 2013, which is considerably below „Imlek's" achievement of $10.62 \%$. All ratios of revenue profitability clearly point out that sales revenue contain a significantly lesser amount of different profit concepts in the case of ,Somboled" than in the case of ,Imlek". The detailed analysis conducted above speaks in favor of the first-stated hypothesis.

Asset and equity profitability ratios, i.e. ROA and ROE are graphically illustrated by means of the following two figures:

Figure 1. ROA ,Imlek“ vs. ,Somboled“

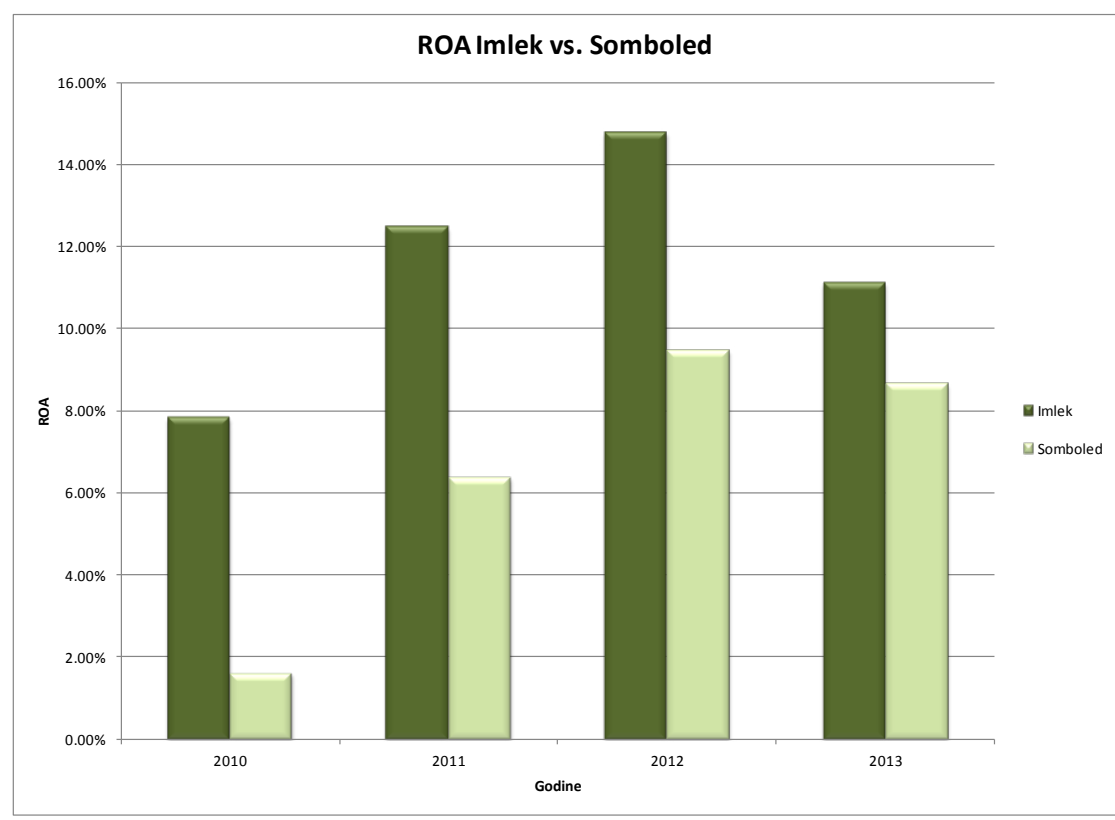

Source: Calculations made by the author on the basis of financial statements available at: http:// fi.apr.gov.rs/prijemfi/cir/objavljivanje.asp 
Figure 2. ROE „Imlek“vs. „Somboled“

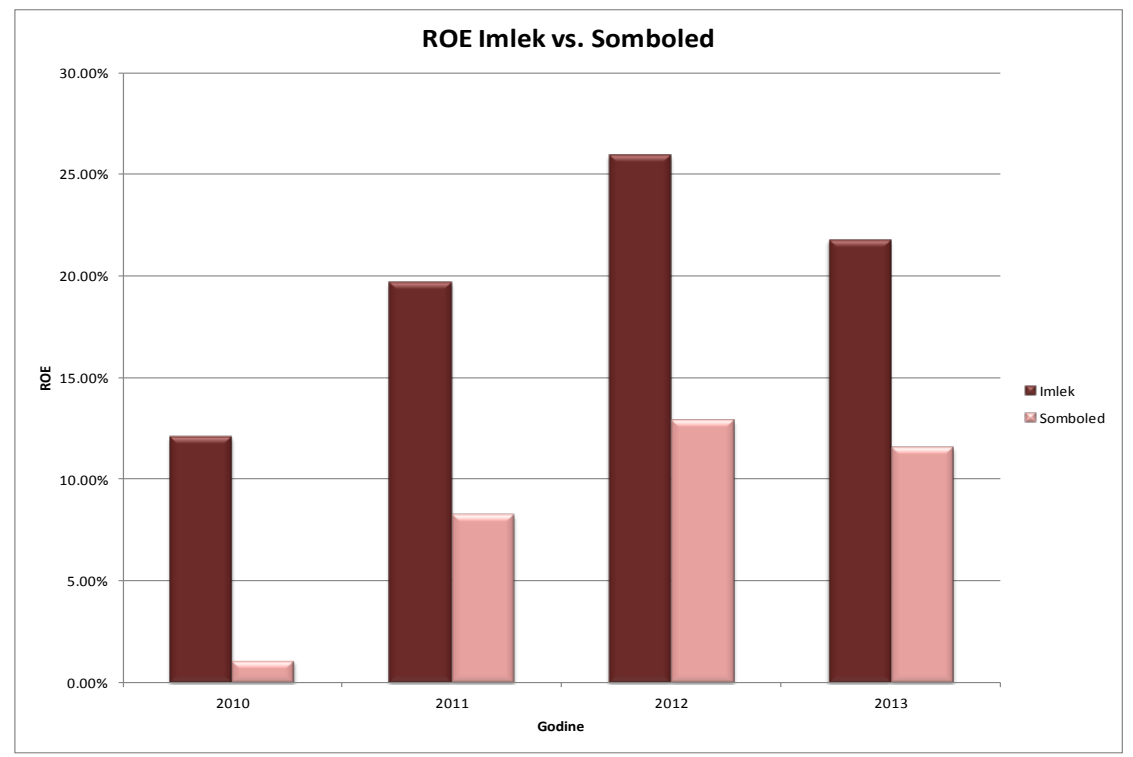

Source: Calculations made by the author on the basis of financial statements available at: $h$ ttp:// fi.apr.gov.rs/prijemfi/cir/objavljivanje.asp

The ROA of „Somboled“ stood at a very low level of only $1.08 \%$ in 2010 due to a very small net profit. During 2011 and 2012, the ROA increased and reached 9.47\% in 2012, but it decreased in 2013. Within the same period of time, ,Imlek's“ ROA was higher than „Somboled's“ but we can see signs which indicate that difference is gradually decreasing.

The ROE of „Somboled“ was on the increase in the period from 2010 to 2012, but it dropped in 2013 as a result of the simultaneous increase in equity and the decrease in earned net profit. The ROE was lower than the ROA in 2010, which signals the presence of the negative financial leverage effect. During each year of the relevant time period, the ROE was higher than the ROA, but the company did not adequately benefit from the positive effect of financial leverage. The same conclusion seems to be valid within the capital structure analysis. The fact that „Somboled“ did not have an either long-term or a short-term financial obligation in 2012 and 2013 is very interesting. By comparing the ROE between „Imlek“ and "Somboled“, I may conclude that the former company appears to be more successful. In 2013, for every $100 \mathrm{RSD}^{6}$ invested by owners, „Imlek“ earned 21.76 RSD net profit, and „Somboled“ only 11.57. This fact additionally supports the first-stated hypothesis.

\section{The Du Pont analysis system}

The advantage of the Du Pont analysis system is that the separation of the rate of return into several components gives us the possibility to identify which „levers" are the ones

6 RSD stands for Serbian Dinar, i.e. national currency 
that the management should simultaneously manage in order to increase profitability. In other words, the management team is able to single out the drivers of value which highlight to the key fields where they should undertake concrete actions in order to acheive the desired results. The goal is that the asset employed in a business should produce as much as possible sales revenues that contain as much as possible profit. The turnover ratios have multiplicative effects on profit margins.

The idea of the Du Pont analysis system is the creation of performance measurement system that can help different levels of management, from operational to strategic, in acheiving the goal of profitability increase (Lohman et al., 2004). By means of the Du Pont analysis system the interpretation of the rates of return is greatly enhanced in terms of quality, which in turn enables the identification of methods for increasing profitability: a more efficient asset and equity management, cost reduction, increase/decrease in selling prices and a better use of the possitive effect of financial leverage. Bearing in mind the interconnection between the factors that affect the rates of return, it is clear that making the right decision is not easy. Cost reduction may lead to a higher profit, but, on the other hand, it is also possible that a reduction of the quality of products as well as the fall in demand may cause a decrease in revenues that could ultimately cancel the positive effects of the reduction of expenses. Moreover, an increase in costs may lead to an increase in both the revenues and the profit margin. The improvement of product quality and the quality of after-sales services (warranties, faster delivery, etc.) inceases costs, but it may also induce a rise in demand and revenues, that could in turn increase profit margins as well as turnover ratios (Malinić, 2010). The Du Pont analysis system for „Imlek“ and „Somboled“ for a four-year period is shown in the following table.

Table 2. Du Pont analysis system: "Imlek" vs. "Somboled", 2010-2013.

\begin{tabular}{|c|c|c|}
\hline \multirow{2}{*}{ Ratio } & Imlek & 2010 \\
\cline { 2 - 3 } 1. ROA (Du Pont) & $7.3081 \% * 1.0728=7.84 \%$ & Somboled \\
\hline \multirow{2}{*}{ 2. ROE (Du Pont) } & $6.3255 \% * 1.9101=12.08 \%$ & $1.1925 \% * 1.3524=1.61 \%$ \\
\hline & $1.7806 * 1.0728 * 7.3081 \% * 0.8655=12.08 \%$ & $1.4257 * 1.3524 * 1.1925 \% * 0.4685=1.08 \%$ \\
\hline 1. ROA (Du Pont) & $11.121 \% * 1.1218=12.48 \%$ & $\mathbf{2 0 1 1}$ \\
\hline 2. ROE (Du Pont) & $10.1519 \% * 1.9385=19.86 \%$ & $2.587 \% * 1.9281=1.08 \%$ \\
\hline & $1.728 * 1.1218 * 11.121 \% * 0.9129=19.86 \%$ & $1.4137 * 1.6429 * 3.8783 \% * 0.9163=8.25 \%$ \\
\hline 1. ROA (Du Pont) & $13.9448 \% * 1.0604=14.79 \%$ & 2012 \\
\hline 2. ROE (Du Pont) & $12.529 \% * 2.0707=25.94 \%$ & $5.2862 \% * 1.7919=9.47 \%$ \\
\hline & $1.9527 * 1.0604 * 13.9448 \% * 0.8985=25.94 \%$ & $1.416 * 1.7919 * 5.2862 \% * 0.9593=12.87 \%$ \\
\hline 1. ROA (Du Pont) & $13.1489 \% * 0.8456=11.12 \%$ & 2013 \\
\hline 2. ROE (Du Pont) & $2.4244 * 0.8456 * 13.1489 * 0.8074=21.76 \%$ & $1.3509 * 1.6837 * 5.1353 \% * 0.991=11.57 \%$ \\
\hline
\end{tabular}

Source: Calculations made by the author on the basis of financial statements available at: http:// fi.apr.gov.rs/prijemfi/cir/objavljivanje.asp 
Within the Du Pont analysis system, ROA is shown as a product of EBIT margin and (total) asset turnover ratio. EBIT margin of „Imlek“ was on the rise throughout the analyzed period of time, but fell in 2013 because of a decrease in net profit. Within the revenue profitability analysis I focused on identifying the reasons for the net profit decrease. The asset turnover ratio showed a substantial decline in 2013, which means that „Imlek“ managed their total assets less efficiently. A decrease in asset management efficiency is also perceived in 2012, but because the EBIT margin increased at a higher rate, ROA was higher in 2012 than in 2011. With regard to ROA in 2013, the decrease in both the EBIT margin and the asset turnover ratio is worrisome. Having in mind that the (total) asset turnover ratio is the most general and synthetic indicator of asset management efficiency, it is necessary to analyze fixed asset and working capital turnover, within which the efficiency of accounts receivable and the management of inventories should be investigated in order to reveal why the asset turnover ratio was decreasing in the observed years.

The fixed asset turnover ratio was recording an increase during the whole observed period. Thus, the problem is in the working capital turnover: this ratio fell in 2013 in comparison with 2012. Sales revenues were rising, but the working capital was rising at a higher rate, which resulted in the fall in the value of the ratio. Within the working capital, the efficiency of accounts receivable was decreasing. The accounts receivable turnover ratio fell in 2013 in comparison with 2012. In terms of credit risk related to accounts receivable collection, a similar amount of gross accounts receivable (in the range from $11.87 \%$ to $13.26 \%$ ) is written off in each of the analyzed years. By observing the age structure of accounts receivable, I can see that in 2012 and 2013, where the collection period was longer than 360 days, the percentage of accounts receivable increased, which is, of course, a bad signal.

Within the Du Pont analysis system, ROE can be shown as a product of two ratios: net profit margin and equity turnover ratio as well as a product of four components: financial leverage, asset turnover ratio, EBIT margin and interest burden. The product of the second and third component in the four-component ROE is equal to ROA, so it can be noticed that there is a close relationship between ROA and ROE. The value of ROA is much more determined by production, marketing and sales capacities of the company, than by the capital structure. However, the capital structure directly affects ROE. In the four-component ROE, the level of the first and the fourth components mentioned above is determined by capital structure, i.e. the combination of debt and equity in asset financing. The formulas for the calculation of financial leverage and interest burden are given below:

Financial leverage $=\frac{\text { Asset }}{\text { Equity }}=\frac{\text { Equity }+ \text { Total Liabilities }}{\text { Equity }}=1+\frac{\text { Total Liabilities }}{\text { Equity }}$

$$
\text { Interest burden }=\frac{\text { Net profit }}{\text { Net profit }+ \text { Interest expenses } x(1-\text { profits tax rate })}
$$

When the company has liabilities, the indicator of financial leverage is always higher than 1 and the indicator of interest burden is always less than 1 . This means that borrowing can cause 
either an increase or a decrease in equity profitability (Malinić et al., 2011).

Financial leverage ratio can be calculated both on the basis of book and market values of equity and debt. The argument that speaks in favor of market values are as follows. Market value of the company finally determines weather the debtholders get their money back. However, market values include the value of intangible assets that are not readily salable and may disappear completely if the company falls in financial distress (Brealey et al., 2011).

In order to identify the effect of financial leverage, i.e. to determine how borrowing affects the profitability of equity, it is necessary to compare ROA with the after-tax cost of debt. For that purpose, ROE is decomposed as follows (Vernimmen et al., 2005):

$\mathrm{ROE}=\mathrm{ROA}+\left\{(\mathrm{ROA}-\right.$ After Tax Cost 6 Debt $\left.) \times \frac{\text { Total Liabilities }}{\text { Equity }}\right\}$

Net profit $=$ ROA $x$ Equity $+($ ROA $x$ Total Liabilities - Interest Expenses $)$

The expression in braces of formula (3) and the one in the parenthesis of formula (4) represent the effect of financial leverage. When return on asset is higher than the after-tax cost of debt, there is a possitive effect of financial leverage that causes ROE to be higher than ROA. However, borrowing also has many disadvantages, such as the costs of financial distress and the agency cost of debt (Ivanišević, 2012). The cost of debt as well as the cost of equity rise with the increase in financial leverage due to a higher risk that investors bear. When the cost of debt increases and becomes equal to ROA, the company should stop borrowing. When the value of ROA becomes less than the cost of debt, i.e. when the return on asset is not enough to cover interest, there is a negative effect of financial leverage and further borrowing decreases equity profitability, i.e. the value of ROE becomes less than that of ROA.

By analysing the two-component ROE of ,Imlek“ I can conclude that the net profit margin was rising in the period from 2010 to 2012, but that it dropped in 2013. The reason for the fall in ROE in 2013 is the abovementioned decrease in net profit. The equity turnover ratio increased in the period from 2010 to 2012, and then fell slightly. The analysis of the fourcomponent ROE provided us with much more information. Two of the four components, i.e. the asset turnover ratio and the EBIT margin, were already analyzed in ROA Du Pont analysis. Now, I am focusing on the company capital structure and the financial leverage effect. Financial leverage decreased in 2011 from 2010. In 2012 and especially in 2013, it increased. During each of the analyzed years there was a positive effect of financial leverage. ROE was higher than ROA, which means that financial leverage influenced a rise in equity profitability. However, it can be noticed that ROE decreased in 2013 from 2012 and that the positive difference between ROE and ROA slightly decreased.

It is necessary to analyze the levels and trends of „Imlek's“ debt ratios. The total liability to equity ratio should have the approximate standard value of 1 , which means that the maximum share of liabilities in financing total assets is 50\%. „Imlek's“ total liability to equity ratio was less than 1 in 2010 and 2011, but it increased in 2012 and 2013 and was higher than 1 in both years. In 2013 the ratio was even equal to 1.61 . 
Given that this is the ratio of total liabilities (both interest and non-interest bearing) to equity, it is advisable to analyze the debt indicator calculated as a ratio of interestbearing liabilities ${ }^{7}$ and equity. „Imlek“ recorded a rapid growth of this ratio in 2012, when the value of 0.97 was recorded, and in 2013 the ratio was equal to 1.3, when the interest-bearing liabilities were higher than equity. This fact additionally supports the statement that the financial leverage of the company increased. Debt-to-equity (D/E) ratio, as a ratio of long-term debt $^{8}$ and (net value) of equity, was also calculated. The ratio increased in 2013 because of the increase in long-term debt.

The causes of rise in debt ratios can be identified by balance sheet analysis. The value of the item Common Stock decreased continuosly during the whole analyzed period because of the cancellation of treasury shares. The value of the item Treasury Shares increased during the observed four-year period.

In terms of liabilities structure, the company had more current than long-term liabilities in each of the observed years. Current liabilities significantly rose in 2012 and 2013. The cause of the rise in current liabilities in 2012 was „Imlek's“ additional borrowing, i.e. an increase in short-term debt. In 2012 there was a rise in other long-term liabilities on the basis of promisory notes which were issued in accordance with the contract for the lease of adveritising slots. This clearly shows that the company has been intensively investing in marketing activities, probably because of the strengthening of competition within the functional foods sector. On the other hand, long-term loans decreased in 2012 because of principal payments.

In 2013 the current liabilities increased additionally. The highest percentage within the current liabilities can be attributed to short-term debt since the banks granted new loans to the company. Long-term debt also increased because of new bank loans aimed at refinancing short-term loans and because of a rise in capital lease obligations caused by the lease of the "Pet Aseptic" production line.

In the following section of the paper I apply the Du Pont analysis system to „Somboled“, the second relevant company. I first focus on ROA analysis. When I analyzed the EBIT margin, I noticed that the ratio increased in the period from 2010 to 2012, but then fell slightly in 2013. In terms of the asset turnover ratio, as the multiplier of the abovementioned profit margin within the two-component ROA, it can be seen that the efficiency of asset management increased in the period from 2010 to 2012, but that it decreased in 2013. Therefore, a decrease in both revenue profitability and asset management efficiency caused the fall in ROA in 2013. It is advisable to analyze the turnover ratios of different types of total assets: fixed assets, accounts receivable, inventories, etc. The fixed asset turnover ratio decreased slightly as a result of a rise in fixed assets which was followed by a slower growth in sales revenue. The decrease in fixed asset turnover is not a cause for concern if the investments are profitable and if their positive effects are likely to be

7 Interest-bearing liabilities are calculated as a sum of long-term provisions, long-term liabilities and short-term financial liabilities.

8 Long-term debt is calculated as a sum of long-term provisions and long-term liabilities. 
realized in the foreseeable future. The accounts receivable turnover ratio also decreased. In 2013, an increased investment in accounts receivable was followed by a decrease in sales revenue, which is a very bad sign. Unfortunately, "Somboled's" notes to the financial statements do not include the information about the age structure of the accounts receivable. However, by comparing the accounts receivable turnover ratios of the two relevant companies, it can be concluded that „Imlek“ was more efficient in accounts receivable management than ,Somboled“.

„Somboled's“ asset turnover ratios were higher than „Imlek's“ in each of the observed years which leads to a preliminary conclusion that our second-stated hypothesis makes sense "Somboled", a company which relies on the traditional products in its product assortment, uses the strategy of higher asset turnover. On the other hand, „Imlek's“" gross margin is higher than ,Somboled's“. A thorough analysis conducted in this paper points out the methods which should be used for the increase in profitability of both companies. „Imlek“ should introduce more efficient ways for asset turnover increase, whereas ,Somboled“" should consider how to increase the margins by cost reduction without creating a decrease in product quality, functionality and reliability.

With regard to „Somboled's“" two-component ROE, I analyzed the net profit margin and noticed that it increased, but that it was still significantly lower than „Imlek's“. The second component, the equity turnover ratio, increased in the period from 2010 to 2012, and, as a multiplier of net profit margin, caused ROE to rise more intensively. But, equity turnover decreased in 2013 and caused a fall in ROE.

The four-component ROE is more informative. It gives an insight into the capital structure and the use of positive financial leverage effects. The asset turnover ratio and EBIT margin were already analyzed within ROA in the Du Pont analysis. The further analysis focuses on financial leverage and interest burden. Financial leverage was at its highest in 2010 when ROE was lower than ROA, i.e. when the company suffered a negative financial leverage effect. The financial leverage slightly decreased in 2011 and 2012, but it fell significantly in 2013. The interest burden indicator was very low in 2010: it was equal to 0.4685 only. In the following years, it increased and approached a value of 1 in 2013, which means that interest expenses decreased the net profit to a greater extent. Even though financial leverage was quite stable within the analyzed period, the same cannot be said for the interest burden. The reason for the seemingly inconsistent values of these two debt ratios is the fact that the first indicator took total liabilities in consideration and that the second considered only interest-bearing liabilities while spontaneous sources of financing were irrelevant.

Interest expenses decreased significantly throughout the observed period of time due to a decrease in long-term debt, and in 2012 and 2013 ,Somboled“ did not use long-term debt as a source of financing at all. Short-term debt also decreased and was equal to zero in 2012 and 2013. The fact that the company did not use debt at all in 2012 and 2013 is very surprising and necessitates further analysis. I calculated the cash conversion cycle in order to check whether the company managed to finance the whole operating cycle 
by using spontaneous non-interest bearing sources of financing. However, this proved not to be the case: the cash conversion cycle was positive during whole period and was significantly prolonged in 2013 because of the increase in the average collection period.

The conclusion is that ,Somboled“" should benefit from positive effects of financial leverage to a higher extent. The company should increase the financial leverage to a reasonable level which will result in ROE increase. The debt ratio analysis speaks in favour of this conclusion. The ratio of total liabilities to equity was considerably below the upper approximate standard value of 1 and it considerably decreased throughout the observed period of time. The ratio of interest-bearing liabilities to equity and the D/E ratio stood at a very low point throughout the observed period of time as well.

The findings about financial leverage of „Imlek“" and „Somboled“"stay in line with the main conclusions of the paper that analyzed the determinants of the capital structure in emerging capital markets (Malinić et al., 2013). Namely, the authors concluded that companies from Serbia have much lower debt ratios than companies from other transitional economies. The structure of debt is also specific: short-term debt is higher than long-term debt.

There is close relation between profitability and capital structure. Only profitable companies are able to provide internal financing sources. Profitability is also positive sign for investors, that ultimately lead to long-term sustainable growth (Malinić, 2013).

There are two types of liabilities, financial and operating. So there are two types of leverage coming from liabilities that can differently affect ROE. One leverage effect comes from borrowing to finance operations and the second from borrowing in the course of operations (Nissim, Penman, 2003).

\section{The analysis of the level and the structure of specific kinds of costs}

As mentioned above, it is to be expected that "Imlek" should have higher specific kinds of costs than "Somboled". These specific kinds of costs include marketing costs, sponsorship costs, costs of raw milk, costs of the quality analysis of final products, consultancy costs, etc. Most of these costs fall within the scope of the costs that can produce additional revenues. It is also expected that the difference in costs between two relevant companies will be decreasing because of "Somboled's" more active presence on the functional food market. It also means that "Somboled" must make some specific investments in order to become more recognizable as a brand by functional food consumers. The vertical analysis of income statements was done in order to test the stated hypothesis. I analyzed the relation between some cost categories and operating revenues/operating expenses. However, the problem that I encountered in the vertical analysis of income statements was that some specific cost categories were not represented as separate income statement items, but were sometimes found in notes to the financial statements, which did not have the same form, i.e. they did not include the same items for the companies that were analyzed. The „Imlek's“ notes were richer in information as they contained separate items for costs of raw milk and packaging costs, whereas the relevant notes of ,Somboled“" only contained an aggregate item for direct material costs. Additionally, the item marked as Other Operating Expenses included more subitems in the case of „Imlek“, 
such as advertising and sponsorship costs, the costs of the quality analysis of raw milk and final products, the cost of hygiene maintenance, etc. The item Consultancy Costs was given as an aggregate sum which included the cost of services of healthcare consultants, lawyers, auditors and other consultants. Such an aggregate sum of costs was useless for the purpose of my analysis. "Somboled's" notes contained only the costs of advertising and representation as the components subsumed under the item Other Operating Expenses, but other relevant subitems were not mentioned. Likewise, external consultancy costs and severance costs were also subsumed under one aggregate item. This item was also very heterogeneous and hence useless for the purpose of my analysis. In accordance with the objectives of the analysis, clearly separated cost items would have played a major role in determining which cost items reflect the costs of the specific technology used for functional food production.

"Imlek's" production technology is specific because it has more functional foods in the product assortment. Its operating cycle, as well as its inventory period, were both longer than "Somboled's" throughout the relevant period of time. However, by reading the Management Discussion and Analysis Report (MD\&A), it can be noticed that ,Imlek“" neither significantly invested in research and development of its core business, nor in the information technologies and human resources both in 2012 and 2013, which represents a potentially bad outlook for the future of the company. In terms of investment, the most important project was related to the processes of upgrading the production, the packaging equipment and the production infrastructure.

The „Imlek's“" percentage share of the advertising, sponsorship and representation costs in operating revenues/operating expenses decreased while the reverse is true for „Somboled“" This could mean that the latter company invests more in its functional food marketing since it entered that market segment at a later stage and is now a follower.

The possibilities for testing the third-stated hypothesis in greater detail are limited due to my restricted access to data contained only in the financial statements which are made publicly available.

\section{Conclusion}

The main contribution of this paper represents a detailed quantitative financial analysis of the profitability of two companies which fall within the domain of a specific sector of N\&H claimed food producers, where one of the analyzed companies is, hypothetically speaking, a leader on the functional food market, and the other is a follower which is gradually entering the market. The ratio analysis was here used primarily as a "signal board" that pointed a direction for further analysis and research and ultimately yielded comprehensive conclusions.

The research hypotheses set at the beginning of this research have been confirmed as valid for both of the companies which represent the focus of my analysis. The profitability ratio analysis of ,Imlek" and ,Somboled" has shown that the former company, i.e. the one that is more recognizable as functional food producer, has higher profit margins, while the latter, which is still focussed on producing traditional foods, centres its profitability on the strategy of higher asset turnover. „Imlek ${ }^{6}$ also has higher rates of return. The detailed debt ratio 
analysis and the analysis of the financial leverage effect showed that the benefits of „Imlek“ are based on the positive financial leverage effects to a substantially higher extent than those of,,Somboled“. Although it is expected that some kinds of costs of, Imlek“" will be higher due to its specific technology which is employed for functional food production and its potentially more extensive marketing activities, I have not managed to completely test this hypothesis because I mostly relied on the data from the financial statements that are publicly available.

However, it is important to bear in mind that the difference in product assortment between the two analyzed companies and the fact that one company is, hypothetically speaking, a leader and the second is a follower, constitute only two of many causes for the difference in profitability. Since we do not want to make general conclusions on the basis of the financial analysis conducted for the purpose of the analysis of the profitability of these two companies per se, we cannot be sure whether the conclusions reached in the particular case of ,Imlek“" are valid for all companies that mostly produce functional foods - the observations made in the case of ,Somboled" cannot be applied to all companies that mostly produce traditional foods.

The financial analysis that I have conducted in this paper pertains to the companies as a whole, even though they actually have a mixed product assortment. However, what is important is that the first relevant company is recognizable as functional food producer, while the second is generally viewed as a traditional food producer. These financial analyzes could be conducted in an even greater detail if the companies had reports which were clearly delineated into segments: in that case, we would be able to make comparisons between the functional food and traditional food segments. Unfortunatelly, the analyzed companies are not organised in segments in accordance with the IAS 14 and it is therefore not possible to analyze and keep track of individual products and product groups profitability.

Since ,Somboled“ is organised as a limited liability company, it is not possible to apply the market value ratio analysis. This type of analysis, where accounting and market data are combined, would certainly give me a better insight into the causes of profitability differences between the two companies since the market price of shares is a unique overarching indicator of past, current and projected future company performances.

Within the vertical analysis of income statements, where I tried to find the differences which account for the share of some costs in operating revenues, the conclusion would certainly be more plausible if the notes to the financial statements included a more detailed cost structure and if the items were more comparable between companies.

Financial statements, which represent the basis of information for my financial analysis, are ex-post documents but they are also the best foundation for the projection of company's future performances. They are published on a regular basis and are publicly available to all stakeholders. The financial analysis serves as a compass as well as a reliable guideline for the choice of the appropriate develompental course which is intended to enhance the progress of a company. The problem with financial statements as a source of data can be attributed to the use of different accounting policies that certainly hinder comparison. The compulsory compliance with the International Accounting Standards enhances the quality of financial 
statements and analysis, limits the choices in terms of different accounting policies and leads to an increasing number of claims for disclosures. The need for financial statements to be subjected to exhaustive external and internal auditing practices is very important for ensuring the validity and reliability of information.

Future research should focus on the analysis of the value creation process within a company by using the value performance measures such as EVA (Economic Value Added) and MVA (Market Value Added). Moreover, it would be interesting to keep track of ratios analyzed in this paper within the following time period in order to make comparisons for longer time series. If „Somboled“ changes its legal form and becomes a publicly limited company in the following years, then it will be useful to apply the market value ratio analysis. It is of the utmost importance to analyze the profitability of products and group of products and to make comparisons between N\&H claimed and traditional ones. Additionally, it would be interesting to analyze the market shares of the companies, the market concetration measures, as well as the M\&A (Mergers and Aquisitions) transactions and their effects on the profitability of the company or group of companies.

\section{Appendix 1}

Used formulas:

Gross margin $=\frac{\text { Gross profit }}{\text { Sales revenue }} \times 100$

Operating profit margin $=\frac{\text { Operating profit }}{\text { Sales revenue }} \times 100$

Profit margin $=\frac{\text { Net profit }}{\text { Sales revenue }} \times 100$

EBIT margin $=\frac{\text { Net profit }+ \text { Interest expenses } \times(1-\text { Profits tax rate })}{\text { Sales revenue }} \times 100$

$\mathrm{ROA}=\frac{\text { Net profit }+ \text { Interest expenses } \mathrm{x}(1-\text { Profits tax rate })}{\text { Average asset }} \times 100$

$\mathrm{ROE}=\frac{\text { Net profit }}{\text { Average equity }} \times 100$

Asset turnover ratio $=\frac{\text { Sales revenue }}{\text { Average asset }}$ 
Equity turnover ratio $=\frac{\text { Sales revenue }}{\text { Average equity }}$

Fixed asset turnover ratio $=\frac{\text { Sales revenue }}{\text { Average fixed asset }}$

Accounts receivable turnover ratio $=\frac{\text { Sales revenue }(\text { at external market })}{\text { Average accounts receivable }}$

Accounts payable turnover ratio $=\frac{\text { Total supplier purchases }}{\text { Average accounts payable }}$

Inventory turnover ratio $=\frac{\text { Costs } 6 \text { goods sold }}{\text { Average inventory }}$

\section{Literature}

1. Agencija za privredne registre, financial statements of companies „Imlek“ and „Somboled“, available at: www.apr.gov.rs (http://fi.apr.gov.rs/prijemfi/cir/Podaci1. asp? Search $=07042701 \& \operatorname{code}=29 \mathrm{~d} 1 \mathrm{ebedc} 140 \mathrm{fd} 4 \mathrm{~d} 8 \mathrm{e} 3 \mathrm{f} 0$ eada $5 \mathrm{bde} 7 \mathrm{cb} 8175 \mathrm{~d} 006$ and http://fi.apr.gov.rs/prijemfi/cir/Podaci1.asp?Search $=08067953 \&$ code $=00$ ce $7 \mathrm{a} 7$ 4d7b161b83dfc00b86abbf96327038c33)

2. Brealey, R., Myers, S., Allen, F. (2011): Principles of Corporate Finance, McGrawHill Irvin, New York, USA.

3. Diplock, A. T., Agget, P. J., Ashwell, M., Bornet, F., Fern, E. B., Roberfroid, M. B. (1999): Scientific Concepts of Functional Foods in Europe: Consensus Document, British Journal of Nutrition, vol. 81, no. 1, pp. 1-27, Cambridge University Press on behalf of The Nutrition Society, United Kingdom.

4. Dragutinović Mitrović, R., Gligorić, M., Cvetković, M. (2014): Kvantitativna analiza tržišta, u knjizi - Tržište hrane sa NiZ izjavom na Zapadnom Balkanu: Stanje, izazovi i perspektive, (urednici) Stojanović, Ž., Dragutinović Mitrović, R., Ognjanov, G., pp. 23-38, CID Ekonomskog fakulteta, Beograd, Srbija.

5. Goddard, J., Tavakoli, M., Wilson, J. (2009): Sources of Variation in Firm Profitability and Growth, Journal of Business Research, vol. 62, no. 4, pp. 495-509, Elseiver, Amsterdam, The Netherlands.

6. Ivanišević, M. (2012), Poslovne finansije, CID Ekonomskog fakulteta, Beograd, Srbija.

7. Lohman, C., Fortuin, L., Wouters, M. (2004): Designing a Performance Measurement System: A Case Study, European Journal of Operational Research, vol. 156, no. 2, pp. 267-286, Elseiver, Amsterdam, The Netherlands. 
8. Malinić, D. (2010): Finansijski benčmarking kao instrument za unapređenje performansi preduzeća, Zbornik radova sa Simpozijuma Saveza računovođa i revizora Republike Srpske - Uloga finansijske i računovodstvene profesije u prevazilaženju krize u realnom i finansijskom sektoru, Banja Vrućica, Republika Srpska, vol. 14, pp. 155-179.

9. Malinić, D. (2013): Insufficiency of Serbian Economy's Operating Performances: Manifestations, Causes and Main Guidelines of Recovery, Ekonomika preduzeća, vol. 61, no. 1-2, pp. 41-62, Serbian Association of Economists, Belgrade, Serbia.

10. Malinić, D., Denčić-Mihajlov, K., Ljubenović, E. (2013): The Determinants of Capital Structure in Emerging Capital Markets: Evidence from Serbia, European Research Studies, vol. 16, no. 2, pp. 98-119, University of Piraeus, International Strategic Management Association, Piraeus, Greece.

11. Malinić, D., Milićević, V., Stevanović, N. (2011): Upravljačko računovodstvo, CID Ekonomskog fakulteta, Beograd, Srbija.

12. Mitić, S., Gligorijević, M. (2014): Kvalitativno istraživanje stavova potrošača o oznakama na hrani, u knjizi - Marketing prehrambenih proizvoda, ch. no. 2, (urednici) Mitić, S., Ognjanov, G., pp. 73-94, Dosije studio, Beograd, Srbija.

13. Nissim, D., Penman, S. (2003): Financial Statement Analysis of Leverage and How It Informs About Profitability and Price-to-Book Ratios, Review of Accounting Studies, vol. 8, no. 4, pp. 531-560, Springer-Verlag New York, Inc., New York, USA.

14. Seling, T., Stickney, C. (1989): The Effects of Business Environment and Strategy on a Firm's Rate of Return on Assets, Financial Analysts Journal, vol. 45, no.1, pp. 43-68, CFA Institute, Charlottesville, USA

15. Stojanović, Ž., Dragutinović Mitrović, R., Ognjanov, G. (2013, a), Processors and retailers attitudes towards consumer demand for dairy nutrition and health claimed products in Western Balkan Countries, in Book - Consumer attitudes to food quality product, ch. no. 2, (editors) Klopčić, M., Kuipers, A., Hocquette, J.F., pp. 135-146, Wageningen Academic Publihers, The Netherlands.

16. Stojanović, Ž., Filipović, J., Stojković, D. (2014): Tržište hrane sa NiZ izjavom: perspektive proizvođača i maloprodavaca, Ekonomski horizonti, vol. 16, no. 1, pp. 63-75, Ekonomski fakultet Univerziteta u Kragujevcu, Kragujevac, Srbija.

17. Stojanović, Ž., Ognjanov, G., Spiroski, I., Zaouche-Laniau, M. (2013, b): Exploring an Emerging Market through Focus Groups and Expert Interviews: Health Claimed Products in the Western Balkans, in Book - Food Consumer Science: Theories, Methods and Application to the Western Balkans, ch. no. 5, pp. 57-72, (editors) Barjolle, D., Gorton, M., Milošević Đorđević, J., Stojanović, Ž., Springer, New York, London.

18. Vernimmen, P., Quiry, P., Dallocchio, Le Fur. J., Salvi, A. (2005): Corporate Finance - Theory and Practice, John Wiley \& Sons, LtD. 
19. Web site of the company "Imlek", www.imlek.rs/en

20. Web site of the company "Somboled", www.somboled.rs and www.somboled.rs/ en/magazine/healthy-diet/functional-food

\title{
KOMPARATIVNA ANALIZA RENTABILNOSTI PROIZVOĐAČA FUNKCIONALNE HRANE U SRBIJI - ODNOS LIDER-PRATILAC
}

\author{
Dragana Draganac 9
}

\begin{abstract}
Rezime
Tržište funkcionalne hrane je relativno mlado u Srbiji i nedovoljno istraženo, kako sa aspekta proizvođača, tako i sa aspekta potrošača, kako sa kvalitativnog, tako posebno sa kvantitativnog aspekta. Cilj ovog rada je da napravi sveobuhvatnu kvantitativnu finansijsku analizu rentabilnosti na primeru dva preduzeća, gde je kriterijum za izbor to što se jedno od njih na tržištu prepoznaje kao proizvođač hrane sa nutritivnim $i$ zdravstvenim izjavama i lider je na tom segmentu tržišta, a kod drugog su zastupljeniji tradicionalni proizvodi i kasnije je ušlo na ovaj segment tržišta. Ključna ideja je da se izvrši komparativna analiza zarađivačke sposobnosti ova dva tipa preduzeća za period od četiri godine. U radu je sprovedena racio analiza profitabilnosti, Du Pont sistem analize, analizirana je zaduženost $i$ efekat finansijskog leveridža, a napravljena je $i$ vertikalna analiza bilansa uspeha, da bi se videlo učešće pojedinih troškova u poslovnim prihodima. Dobijeni rezultati upućuju na zaključak da prvo analizirano preduzeće, koji je na tržištu prepoznato kao proizvođač funkcionalne hrane, ima više profitne marže. Takođe, ostvaruje više stope prinosa, a zbog toga može da, u većem stepenu, koristi pozitivne efekte finansijskog leveridža. Drugo istraživano preduzeće svoju rentabilnost uglavnom bazira na bržem obrtu imovine.
\end{abstract}

Ključne reči: rentabilnost, finansijski leveridž, proizvođači funkcionalne hrane

9 Dragana Draganac, Asistent u nastavi, Univerzitet u Beogradu, Ekonomski fakultet, Kamenička ulica br. 6, 11000 Beograd, Republika Srbija, Telefon: +381 113021177 , E-mail: dragana_c@ekof.bg.ac.rs 